\title{
Impact of Yoga Nidra as Natural Tranquilizer in Emotional Pain
}

\author{
Bhavika Joshi
}

PhD Scholar, Mphil in Ashtanga Yoga, Net Qualified (Yoga), Lakulish Yoga University, Ahmedabad.

\begin{abstract}
As a science of wellbeing, Yoga needs not more introduction. In this modern time Yoga practices utilize as preventive as well as curative aspects. In this article, affect of an ancient yogic Practice called Yoga Nidra can discharge emotional blockages and tie of pain. Emotional suffering is suffering or harmed that originates from non physical sources. In modern time individual may endure from this sort of suffering habitually due to parts of reasons. When an individual cannot express his/her sentiments and suppress that, it may create emotional blockages in mind. Yoga Nidra practice work as tool to help this sort of suffering and work as tranquilizer.
\end{abstract}

Key Words:- Emotional pain, Yoga Practice, Yoga Nidra.

\section{INTRODUCTION}

The term Yoga Nidra is originated from two Sanskrit words. Yoga meaning union or mindfulness, and Nidra which implies rest. Swami Satyananda Saraswati (2002) clarifies Yoga Nidra as a state of intellect between attentiveness and dream. According to ancient Indian sacred texts, sages are known to rest utilizing Yoga Nidra. Yoga Nidra is inferred from Pratyahar of Raja Yoga and tantric practice of Nyasa. Practice of Yoga Nidra, one shows up to be sleeping, but the awareness is working at a more profound level of mindfulness. For this reason, Yoga Nidra is regularly inrodued to as "Psychic sleep" or "Deep relaxation with inner awareness.",

Yoga Nidra is well known practice for physical, mental and emotional health through unwinding. Yoga Nidra, which is originated from the tantras. Yoga Nidra could be a capable strategy in which learn to relax deliberately. In Yoga Nidra, rest isn't respected as unwinding. This is as sensory diversion. Genuine relaxation is really a far beyond all this. Yoga Nidra is state of energetic rest. ${ }^{1}$ Yoga nidra may be a orderly strategy of actuating complete physical, mental and emotional relaxation. Yoga nidra may be an effective pressure soothing technique in which you'll learn to relax knowingly. Yoga Nidra can be utilized for more prominent mindfulness, productivity and accomplishment in life, it empowers an adjust of psychic and imperative energies. When we practice Yoga Nidra we enter a state of very deep relaxation in which we travel through the layers of our conscious, subconscious and unconscious minds. ${ }^{1}$

In Hatha Yoga Pradipika, great yogi Swatmarama, classifies Yoga nidra as the state of turiya, means the all expansive and encompassing 'fourth dimension'. In this Shakti neither contracts nor expands, but is in union with Shiv or supreme counsiousness. ${ }^{2}$

Emotional pain could be a state of feeling broken that involved the encounter of being injured, misfortune of self, detachment and basic awareness of one's more negative attributes. ${ }^{3}$ The universal affiliation for the think about of pain characterized pain as an unsavoury tactile and passionate encounter related with real or potential tissue damage. Emotional pain or mental pain is an unpleasant feeling of 
mental or non physical origin. Technical terms include algopsychalia and psychalgia but it may too be called mental pain, emotional pain, psychic pain, social pain, otherworldly pain, or sufferings. ${ }^{3}$

Emotional pain can frequently feel as solid as physical pain. It can indeed cause side effects of pain all through the body. It can too have an inconvenient affect on both short-term and long-term mental wellbeing. ${ }^{4}$ Typically exceptionally vital to treat the enthusiastic pain. There are numerous ways to oversee these sort of emotional pain like talking to a few one (social support), Physical movement, Relaxation and mindfulness Relaxation strategies, such as reflection, tuning in to music, tuning in to guided symbolism tracks, yoga, and Tai Chi are valuable ways to bring your feelings into balance. Yoga is appropriate way to oversee the emotional balance.

Tranquilizer, drug that's utilized to diminish uneasiness, fear, pressure, tumult, and related states of mental disturbance. ${ }^{5}$ In this article, I am discussing the impact of yoga nidra as a natural tranquilizer, through the healing mechanism of yoga nidra during emotional pain.

\section{Relationship between emotional pain and physical pain:-}

Studies over the years have shown chronic pain may be caused by both physical injury or trauma and emotional issues. The team at south west spine and pain centre discusses how physical pain and emotional pain are connected to each other. The physical discomfort is often a signal to the brain that emotional traumas needs to be resolved to reduce tension and other issues affected the nervous system.

According to doctor Susan Babel certain body pain may indicate different emotional problems. Although not all pain is caused by emotional stresses or traumas, it can definitely play a huge role in our overall health and wellbeing.

In modern time person may suffer from this type of emotional pain mostly due to results of the actions of others.
Sometimes it might be the result of regret, grief or loss. This type of emotional pain is very common in our life, so management of this type of pain is require for healthy living.

\section{Process of Yoga Nidra:-}

The 8 stages of the Yoga Nidra practice include:

- Internalization / Relaxation Preliminary preparation of the body.

- Affirmation (Sankalpa) - A personal goal previously decided upon is declared silently.

- Rotation of Consciousness - The consciousness is taken on a tour of the whole body in a structured fashion.

- Respiration awareness - A period of awareness of the breath at special positions in the body.

- Manifestations of Opposites - Pairs of feelings and emotions are experienced.

- Creative Visualization - Various Archetypal images are visualized mentally.

- Affirmation- Sankalpa is repeated and, now in a highly suggestible state of consciousness, is programmed into the subconscious mind.

- Return to Full Awareness - A careful and gradual return to a normal state ${ }^{1}$

\section{Benefits:-}

- Everybody can practice, Indeed apprentices who have no involvement with meditation.

- Physical stresses and pressures are removed.

- Mental stresses and undesirable impressions are removed.

- Emotions adjust is restored.

- The resources of creative energy and visualization are polished and enhanced.

- The subliminal is focussed on and able to manifest any individual objective be it physical. $^{1}$ 
Effect of Yoga Nidra on emotional and Mental Health:-

It can help within the accomplishment of a state of so called selfrealization (total self-awareness) Yoga Nidra makes a difference in re-establishing mental, emotional and physical wellbeing by way of unwinding, and makes the intellect more conducive to Pratyahara withdrawing faculties from their objects, Dharana - concentration, and reflection. The practice helps harmonize the two halves of the globe of the brain and the two angles of the independent apprehensive system (sympathetic and parasympathetic). ${ }^{7}$

\section{Typical Effects}

The most easily observable effect of the Yoga Nidra practice is the extremely deep relaxation of the nervous system and healing of the body by allowing it the rest and recharge it usually lacks in our all too busy lifestyles. Yoga Nidra has been clinically shown to be one of the most powerful methods available to achieve this state of deep relaxation and sedation without the use of chemical agents. In Yoga Nidra exactly opposite process is used to make the brain centres active by focussing awareness on the parts of the body in a definite sequence. Thus, the person tries to stimulate various parts of the brain by focusing the awareness on the corresponding parts of the body. By awareness is implied 'attitude of witnessing' towards physical or mental actions of the body. ${ }^{7}$

\section{Healing mechanism of yoga nidra:-}

Yogic logic as well as advanced psychology, enumerates three fundamental sorts of pressure which are responsible for all the desolations of cutting edge life. These three sorts of pressure are classified as Physical, Mental and emotional. Through the consistent practice of Yoga Nidra, these threefold tensions can be dynamically discharged. 1. Physical Tension- Usually named as solid tensions related to the body itself, the apprehensive framework and endocrinal lopsidedness. These are easily released by the profound physical unwinding achieved within the state of Yoga Nidra. 2. Emotional Pressure- It controls the emotional state of the intellect, anesthetize the entire emotional structure of the intellect. 3. Mental tension:- Everyone included in a few kind of mental activity in day to day life. The intellect is whirlpool of fantasies, disarrays and oscillations. The tensions related to family, working environment, and interpersonal relationships are collected within the consciousness state of the mental body. This may bring psychological and behavioural changes in the body responsible for abnormal behaviour of an individual. Yoga Nidra is the science of relaxation which enables to enter into the realms of the subconscious mind, thereby releasing and relaxing mental tensions and establishing harmony in all facts of life. ${ }^{7}$

The Yogic practice leads to heightened cortical arousability and reduced limbic arousability at the same time, which heightened perceptual awareness and simultaneously reduced emotional reaction. Thus the regulatory mechanism in the hypothalamus is set at normal state which results in decreases sympathetic system and stimulates parasympathetic system. There is a powerful technique to cope with the problem of stress without medication in which a person can use their mind to change physiology for the better and improve their health by using the natural restorative process called the Relaxation Response. Yoga Nidra is one of the best Yogic interventional mechanisms to cope with problem of stress which stimulates the parasympathetic system and decreases the sympathetic system which bring the body into homeostatic state. ${ }^{8}$

\section{REVIEW OF LITERATURE}

Rani (2011) investigated the impact of Yoga Nidra on psychological well being in patients with menstrual. The authors studied the association of menstrual symptoms with anxiety and depression in female students. The practice of Yoga Nidra 
has been reported to relieve pain associated with dysmenorrhoea and excessive level of premenstrual tension. The participants in the Yoga Nidra program had found to be decreased level of anxiety, depression and increased positive wellbeing, general health and vitality compared with the control group. ${ }^{9}$

Meenakashi Pathak (2014) studied ,Old age is a stage of life where people may confront a variety of difficulties, including loss of confidence, lowered self-esteem, depression, unmet dependency needs, loneliness, boredom and fear of future. The elderly people habitually transfer their psychological difficulties into physical symptoms and complaints associated with their advancing age. This may lead to rapid physical and mental deterioration in them. This can be easily and effortlessly experienced through amazing energy of Yoga Nidra. Yoga Nidra is a state of mind between wakefulness and dream, in which person sleeps with a trace of awareness. The eight steps of Yoga Nidra (i.e. preparation, relaxation, resolve, rotation of consciousness, breathing, image visualization, resolve, finish) may be applied as an adjuvant to relieve accumulated tensions, stress resistance and psychosomatic diseases, and increases the overall efficiency of geriatric population. ${ }^{10}$

S C Davis (2018) investigated the affect of yoga nidra for reducing emotional pain. Emotional pain can be described as heartache that results from a painful experience, such as being hurt by loved one, as a result of their words or actions. It can occur from depression, anxiety, disappointment, fear or guilt, and tends to worsen when you replay and relive painful, traumatic events that occurred in the past. Emotional pain can become debilitating when it affects your mood, relationships, personal and professional life, and it occupies your mind constantly. ${ }^{11}$

Deskur, M Poonawala, N Bhatewara (2006) found the significance changes in the archers due to the practice of yoga nidra. The effect of Yoga Nidra and Applied
Relaxation Technique (ART) on steadiness and performance of archers was investigated. ART group showed maximum improvement on steadiness task. No statistically significant results were obtained for performance of archers. The findings are discussed in light of the mechanisms and principles underlying these treatments along with their application for sports persons. ${ }^{12}$

K Kumar (2010) finds out the effect of Yoga nidra on regression and guilt on college going students. The result shows a significant change as practice of Yoga nidra positively decreases the regression and guilt levels of both the male and female subjects. $^{13}$

Various studies have been done in different part of world for observing the effect of yoga nidra. I have reviewed many studies on yoga nidra, there are many studies on impact of yoga nidra on stress and its related disease. I have found fewer studies, particular on impact of yoga nidra for reducing emotional pain and emotional transformation.

\section{DISSCUSSION}

Yoga-Nidra is the state of conscious sleeping. Different steps involved in yoganidra have their own effect on mental as well as physical health of the practitioners. The practice of yoga-nidra has shown changes in the functioning of hypothalamus that leads to reduced sympathetic activation and increased parasympathetic activities which are responsible for the body's relaxation. The authors also reported significant reduction in emotional processing and executive control persistent with hypothalamus activity. Reduction in parasympathetic system reduces the release of stress hormone, making an individual feel more composed and stable. These soothing effects as the result of practice of yoga-nidra help in controlling and managing our emotions and thereby reducing emotional pain and work as natural tranquilizer. 


\section{CONCLUSION}

The practice of yogic rest points to bring us to combat with our negative feelings and sentiments that are all as well regularly overlooked in our regular lives. By making space to prepare these sentiments, we are able deliberately ease the inconvenient side impacts cynicism causes on the body and start to discover determination.

It is concluded that the yogic practice like yoga nidra has momentous impact on mental health and emotional pain of the practitioners. This technique is also very useful in treating other physiological and psychological problems. Regular practice of yoga-nidra can be very beneficial for the practitioners. Everyone should make it as the part of the daily routine and experience the impact of yoga nidra as natural tranquilizer.

\section{Acknowledgement: None}

\section{Conflict of Interest: None}

\section{Source of Funding: None}

\section{REFERENCES}

1. Swami Satyanad Saraswati.Yoga Nidra. $6^{\text {th }}$ edition. Munger, Bihar, Yoga Publication trust.1993.

2. K Kumar.Stress free life through yoga nidra. International Symposium on yoga.2010.

3. Daniel W. McNeil. Kevin Larkin. B. Kent Parker. Understanding Emotional Pain: A Preliminary Investigation, Ben Weinstein, West Virginia University,2009

4. Ye Seul Lee, Won-Mo Jung, Hyunchul Jang, Sanghyun Kim, Sun-Yong Chung, Younbyoung Cha, The dynamic relationship between emotional and physical states: an observational study of personal health records, neuropsyctry disease and treatment,(2017);13,411-419.

5. Dr. Richard J. Cross, Tranquilizing drugs, The American Journal of Medicine, (1959);(27)5,767-780.

6. Rachel Cohen,Physical Pain Is In Sync With Emotional Pain, www.southwestspineandpain.com,submitted 06/12/2015 - 10:43am

7. Manish Dwivedi,S K Singh,Yoga Nidra as stress Management Strategy. Purushartha: A Journal of management ethics \& Spirituality,2016;(9)1

8. Panjwani U, Gupta HL, Singh SH, Selvamurthy W, Rai UC. Effect of sahaja yoga practice on stress management in patients of epilepsy. Indian J Physiology Pharmacology.1995; 39: 111-116

9. K Rani,S C Tiwari,Uma Singh. Impact of Yoga Nidra on psychological general wellbeing in patients with menstrual irregularities: A randomized controlled trial. International Journal of Yoga.2011;(4)1.2025

10. Dr. Meenakshi Pathak, Dr. Awadhesh Pandey, Yoga Nidra - An Efficient Adjuvant For Geriatric Health Care, World Journal of Pharmaceutical Research, 2014(4)2.

11. S C Davis, Yoag Nidra to release emotional pain, Journal of yoga practice nad therapy,2018(1)1

12. Deuskar, Poonawala, Effect of Yoga Nidra and Applied Relaxation Technique on Steadiness and Performance of Archers, American psychological association, 2006(51)1,64-68

13. K Kumar, Psychological Changes As Related To Yoga Nidra, International Journal of psychology,2016(6),129-137.

How to cite this article: Joshi B. Impact of yoga nidra as natural tranquilizer in emotional pain. Int J Health Sci Res. 2021; 11(4):156-169. DOI: https://doi.org/10.52403/ijhsr.20210422 